\title{
Produits agricoles en provenance des pays en développement, les possibilités et les limites
}

Mehragrarimporte aus Entwickungsländern; Möglichkeiten und Grenzen

Rudolf Horber

\section{OpenEdition}

Édition électronique

URL : http://journals.openedition.org/aspd/1358

DOI : $10.4000 /$ aspd. 1358

ISSN : 1663-9669

Éditeur

Institut de hautes études internationales et du développement

\section{Édition imprimée}

Date de publication : 1 janvier 1988

Pagination : 187-202

ISSN : 1660-5934

\section{Référence électronique}

Rudolf Horber, «Produits agricoles en provenance des pays en développement, les possibilités et les limites ", Annuaire suisse de politique de développement [En ligne], 7 | 1988, mis en ligne le 05 avril 2013, consulté le 08 septembre 2020. URL : http://journals.openedition.org/aspd/1358 ; DOI : https://

doi.org/10.4000/aspd.1358

Ce document a été généré automatiquement le 8 septembre 2020

(C) The Graduate Institute I Geneva 


\title{
Produits agricoles en provenance des pays en développement, les possibilités et les limites
}

Mehragrarimporte aus Entwickungsländern; Möglichkeiten und Grenzen

\author{
Rudolf Horber
}

\section{NOTE DE L'ÉDITEUR}

En français, résumé seulement. Lire l'article original en allemand dans Schweizerisches Jahrbuch für Entwicklungspolitik : « Mehragrarimporte aus Entwickungsländern; Möglichkeiten und Grenzen ", http://sjep.revues.org/1177.

\section{RÉSUMÉS}

Environ $20 \%$ de nos importations en produits agricoles proviennent des pays en voie de développement Nous savons que ces pays sont eux-mêmes fortement tributaires de l'exportation de produits agricoles, ne serait-il donc pas possible d'améliorer en leur faveur l'accès au marché suisse ainsi qu'aux autres marchés des pays développés? Cette question s'impose d'autant plus que les PVD offrent de grands avantages comparatifs au niveau des matières premières.

Dans cet article, l'auteur tente à démontrer, en s'appuyant sur différents critères, qu'un encouragement approprié des importations agricoles en provenance des PVD n'a de sens que si certaines conditions dans ces pays mêmes sont remplies. Mais quoi qu'il en soit, des mesures autonomes et isolées prises par la Suisse dans le but de favoriser les importations des produits agricoles en provenance des PVD ne sauraient être suffisantes. Il est encore plus important de 
renforcer les mesures prises dans ces pays afin de soutenir davantage et durablement le secteur agricole, et de stimuler les efforts déployés collectivement par les pays industrialisés dans te but d'assainir les marchés mondiaux en réduisant leur production excédentaire et, subséquemment, en améliorant les possibilités d'exportation des PVD. 